\title{
SERTIFIKASI GURU MENUJU PROFESIONALISME PENDIDIK
}

\author{
Muhammad Nasrul Waton \\ Institut Agama Islam Bani Fattah Jombang, Indonesia \\ E-mail: nicerule78@gmail.com
}

\begin{abstract}
An educator or teacher greatly affect the quality of education, because the role of a teacher is to teach a wide range of knowledge to their students. Competence of teachers teaching agent formally evidenced by a certificate of educators. The minimum academic qualifications acquired through higher education, and educators competency certificates obtained after passing the certification exam. The position of teachers as professionals aim to implement the national education system and achieve national education goals, namely the development of students' potentials to become a man of faith and devoted to God Almighty, noble, healthy, knowledgeable, skilled, creative, independent, and became citizens of a democratic and responsible.
\end{abstract}

Keywords: Teacher Sertificate, Profesionalism 


\section{Pendahuluan}

Sudah sering kita mendengar dari berbagai sumber baik dari media elektronik atau cetak, bahwa mutu pendidikan di Indonesia semakin mengkhawatirkan. Hal ini terlihat dari menurunnya peringkat Indonesia dalam HDI (Human Development Index) pada tahun 2011 dari peringkat ke 111 dari 182 Negara ke peringkat 124 dari 187 Negara. ${ }^{1}$ Tentu hal ini bukanlah hal baik untuk mutu pendidikan di negara kita. Kurangnya mutu pendidikan di Indonesia disebabkan oleh berbagai faktor. Salah satu faktor yang mempengaruhi adalah kualitas pendidik atau kualitas guru. Seorang pendidik atau guru sangat berpengaruh pada mutu pendidikan, karena peranan seorang guru adalah mengajarkan berbagai pengetahuan kepada siswanya. Selain itu, seorang guru juga harus mampu mengembangkan segala potensi dan kepribadian siswanya.

Dalam sebuah proses pendidikan, guru merupakan salah satu komponen yang sangat penting karena dianggap mampu memahami, mendalami, melaksanakan, dan akhirnya mencapai tujuan pendidikan. ${ }^{2}$ Guru mempunyai kedudukan sebagai tenaga profesional pada jenjang pendidikan dasar, pendidikan menengah, dan pendidikan anak usia dini pada jalur pendidikan formal yang diangkat sesuai dengan peraturan perundang-undangan. Pengakuan kedudukan guru sebagai tenaga profesional tersebut dibuktikan dengan sertifikat pendidik. Lebih lanjut Undang-Undang Nomor 14 Tahun 2005 tentang guru mendefinisikan bahwa profesional adalah pekerjaan atau kegiatan yang dilakukan oleh seseorang dan menjadi sumber penghasilan kehidupan yang memerlukan keahlian, kemahiran, atau kecakapan yang memenuhi standar mutu atau norma tertentu serta memerlukan pendidikan profesi. ${ }^{3}$

Tenaga pendidik (guru dan dosen) menurut Pasal 39 ayat 2, UU RI No.20 Tahun 2003 tentang Sistem Pendidikan Nasional, Pasal 2 ayat 1, UU RI No.14 Tahun 2005 tentang Guru dan Dosen, dan Pasal 28 ayat (1) PP RI No.19 Tahun 2005 tentang Standar Nasional Pendidikan adalah tenaga profesional. Dengan berpijak pada landasan yuridis dan kebijakan tersebut, secara tegas menunjukkan adanya keseriusan dan komitmen yang tinggi pihak Pemerintah dalam upaya meningkatkan profesionalisme dan penghargaan kepada guru yang muara akhirnya pada peningkatan kualitas pendidikan nasional.

\footnotetext{
${ }^{1}$ Harian Kompas, 4 Desember 2004,

2 Nurdin, Muhamad, Kiat Menjadi Guru Profesional. (Jogjakarta: Ar-Ruzz Media), 17

${ }^{3}$ Kunandar, Guru Profesional; Implementasi Kurikulum KTSP dan Sukses dalam Sertifikasi Guru.(Jakarta: Rajawali Pers.2008)
} 
Memperhatikan arah kebijakan yang diterapkan seperti tersebut di atas, maka pada Pasal 42 UU RI No.20 Tahun 2003 yang menjelaskan syarat bagi pendidik yang harus memiliki kualifikasi minimum dan sertifikasi sesuai dengan kewenangan mengajar, sehat jasmani dan rohani, serta memiliki kemampuan untuk mewujudkan tujuan Pendidikan Nasional. Hal tersebut dipertegas dengan Pasal 28 ayat (1) PP RI No.19 Tahun 2005 tentang Standar Nasional Pendidikan, dan Pasal 8 UU RI No. 14 Tahun 2005 yang mengamanatkan bahwa guru harus memiliki kualifikasi akademik minimal D4/S1 dan kompetensi sebagai agen pembelajaran, yang meliputi kompetensi kepribadian, pedagogis, profesional, dan sosial. Kompetensi guru sebagai agen pembelajaran secara formal dibuktikan dengan sertifikat pendidik. Kualifikasi akademik minimum diperoleh melalui pendidikan tinggi, dan sertifikat kompetensi pendidik diperoleh setelah lulus ujian sertifikasi. ${ }^{4}$

Pengertian sertifikasi secara umum mengacu pada National Commision on Educatinal Services (NCES) disebutkan "Certification is a procedure where by the state evaluates and reviews a teacher candidate's credentials and provides him or her a license to teach". Sertifikasi guru adalah proses pemberian sertifikat pendidik kepada guru. Sertifikat pendidik diberikan kepada guru yang telah memenuhi standar profesional guru. Guru profesional merupakan syarat mutlak untuk menciptakan sistem dan praktik pendidikan yang berkualitas. ${ }^{5}$ Dalam Undang-undang Guru dan Dosen disebut sertifikat pendidik. Pendidik yang dimaksud disini adalah guru dan dosen. Proses pemberian sertifikat pendidik untuk guru disebut sertifikasi guru, dan untuk dosen disebut sertifikasi dosen. Sertifikat pendidik adalah sebuah sertifikat yang ditandatangani oleh perguruan tinggi penyelenggara sertifikasi sebagai bukti formal pengakuan profesionalitas guru yang diberikan kepada guru sebagai tenaga profesional.

Dengan adanya sertifikasi tersebut, guru diharapkan mampu meningkatkan kinerja yang lebih baik sehingga peningkatan mutu pendidikan akan berjalan ke arah yang lebih baik pula. Di samping itu, diharapkan agar guru sebagai tenaga profesional dapat berfungsi untuk meningkatkan martabat dan peran guru sebagai agen pembelajaran dan berfungsi untuk meningkatkan mutu pendidikan nasional, serta

\footnotetext{
${ }^{4}$ Samani, Mucklas dkk. Mengenai Sertifikasi Guru di Indonesia. (Surabaya: SIC 2006), 32

${ }^{5}$ Fajar, Arnie, Peranan Sertifikasi Guru Dalam Meningkatkan Profesionalisme Guru. Dalam Makalah Seminar nasional Sosialisasi Sertifikasi Guru dalam memaknai UU No.14 Tahun 2005. (Bandung: Disdik Jawa Barat 2006)
} 
meningkatnya mutu pembelajaran dan mutu pendidikan secara berkelanjutan. 


\section{Pembahasan}

1. Sertifikasi Guru

Dasar dari pelaksanaan sertifikasi adalah Undang-undang Nomor 14 Tahun 2005 tentang Guru dan Dosen (Undang-undang Guru Dan Dosen) yang disahkan tanggal 30 Desember 2005. Pasal yang menyatakannya adalah pasal (8); "guru wajib memiliki kualifikasi akademik, kompetensi, sertifikat pendidik, sehat jasmani dan rohani, serta memiliki kemampuan untuk mewujudkan tujuan pendidikan nasional." Pasal lainnya adalah Pasal 11 ayat (1) menyebutkan bahwa "sertifikat pendidik sebagaimana dalam pasal 8 diberikan kepada guru yang telab memenubi persyaratan." Landasan hukum lainnya adalah Undang-undang Nomor 20 Tahun 2003 tentang Sistem Pendidikan Nasional, dan Peraturan Menteri Pendidikan Nasional Nomor 18 Tahun 2007 tentang Sertifikasi bagi Guru dalam Jabatan.

Perlunya ada sertifikat pendidik bagi guru dan dosen, bukan saja untuk memenuhi persyaratan sebuah profesi yang menuntut adanya kualifikasi minimum dan sertifikasi, juga dimaksudkan agar guru dan dosen dapat diberi tunjangan profesi oleh negara. Tunjangan profesi itu diperlukan sebagai syarat mutlak sebuah profesi agar penyandang profesi dapat hidup layak dan memadai, apalagi hingga saat ini guru dan dosen masih tergolong kelompok yang berpengahasilan rendah yang harus dibantu meningkatkan kesejahteraan melalui undangundang.

Dengan kata lain tujuan sertifikasi untuk meningkatkan mutu dan menentukan kelayakan guru dalam melaksanakan tugas sebagai agen pembelajaran dan mewujudkan tujuan pendidikan nasional. Adapun manfaat yang nantinya akan dirasakan setelah sertifikasi guru dilaksanakan dapat dirinci sebagai berikut: ${ }^{6}$

a. Melindungi profesi guru dari praktik-praktik yang tidak kompeten, yang dapat merusak citra profesi guru.

b. Melindungi masyarakat dari praktik-praktik pendidikan yang tidak berkualitas dan tidak profesional.

c. Menjadi wahana penjaminan mutu bagi LPTK, dan kontrol mutu dan jumlah guru bagi pengguna layanan pendidikan.

d. Menjaga lembaga penyelenggara pendidikan (LPTK) dari keinginan internal dan tekanan eksternal yang menyimpang dari ketentuanketentuan yang berlaku.

${ }^{6}$ Muslich, Masnur. Sertifikasi Guru Menuju Profesionalisme Pendidik. (PT Bumi Aksara Jakarta, 2007), 9 

e. Meningkatkan kesejahteraan guru dengan adanya tunjangan profesi.

2. Profesionalisme

Sesungguhnya paradigma baru pendidikan nasional, telah menempatkan pendidik sebagai tenaga profesional yang bertugas merencanakan dan melaksanakan proses pembelajaran, menilai hasil pembelajaran, melakukan pembimbingan dan pelatihan, serta melakukan penelitian dan pengabdian masyarakat. Dalam ketentuan umum Undang Undang Guru dan Dosen (pasal 1) pengertian professional diberi rumusan: "Profesional adalab kegiatan atau yang dilakukan seseorang dan menjadi sumber penghasilan kehidupan yang memerlukan keablian, kemabiran atau kecakapan yang memenubi standar mutu atau norma tertentu, serta memerlukan pendidikan profesi”. Sejalan dengan hal tersebut disebutkan bahwa profesional mengharuskan adanya pembayaran untuk melakukannya.

Selanjutnya pasal 7 ayat 1 Undang Undang Guru dan Dosen ditetapkan dengan jelas sembilan prinsip professional yaitu guru dan dosen:

a. Memiliki bakat, minat dan panggilan jiwa dan idealisme.

b. Memiliki komitmen untuk meningkatkan mutu pendidikan, keimanan, ketaqwaan, dan akhlak mulia.

c. Memiliki kualifikasi akademik dan latar belakang pendidikan sosial dengan bidang tugas.

d. Memiliki kompetensi yang diperlukan sesuai dengan bidang tugas,

e. memiliki tanggung jawab atas pelaksanaan tugas keprofesionalan.

f. Memperoleh penghasilan yang ditentukan sesuai dengan prestasi kerja.

g. Memiliki kesempatan untuk mengembangkan keprofesionalan secara berkelanjutan dengan belajar sepanjang hayat.

h. Memiliki jaminan perlindungan hukum dalam melaksanakan tugas keprofesionalannya

i. Memiliki organisasi profesi yang mempunyai kewenangan mengatur hal- hal berkaitan dengan tugas keprofesionalan guru.

Pemberdayaan profesi guru atau pemberdayaan profesi dosen dilaksanakan melalui pengembangan diri yang dilakukan secara demokratis, berkeadilan, tidak diskriminatif dan berkelanjutan dengan

\footnotetext{
7 Poerwadarminta, W.J.S. Kamus Umum Bahasa Indonesia. (Jakarta: Balai Pustaka, 2007). 911
} 
menjunjung tinggi hak asasi manusia, nilai keagamaan, nilai kultural, kemajemukan bangsa, dan kode etik organisasi profesi. Profesi itu merupakan suatu jenis pelayanan atau pekerjaan yang unik (khas), dalam arti berbeda dari jenis pekerjaan atau pelayanan apapun yang lainnya. ${ }^{8}$

Selain itu, dalam pasal 1 ayat 1 butir 1 Undang Undang Guru dan Dosen ditetapkan bahwa guru adalah pendidik profesional dengan tugas utama mendidik, mengajar, membimbing, mengarahkan, melatih, menilai, dan mengevaluasi peserta didik pada jalur pendidikan formal, pendidikan dasar, dan pendidikan menengah termasuk pendidikan usia dini.

Kedudukan guru sebagai tenaga professional diatur lebih rinci pada pasal 2 ayat 1 Undang Undang Guru dan Dosen, bahwa guru mempunyai kedudukan sebagai tenaga profesional pada jenjang pendidikan dasar, pendidikan menengah, dan pendidikan anak usia dini pada jalur pendidikan formal yang diangkat sesuai dengan peraturan perundang-undangan. Pengakuan kedudukan guru sebagai tenaga profesional dibuktikan dengan sertifikat pendidik.

Pengakuan kedudukan guru sebagai tenaga profesional yang dibuktikan dengan sertifikat pendidik berfungsi untuk meningkatkan martabat dan peran guru sebagai agen pembelajaran dalam meningkatkan mutu pendidikan. Selanjutnya, kedudukan guru sebagai tenaga professional bertujuan untuk melaksanakan sistem pendidikan nasional dan mewujudkan tujuan pendidikan nasional, yaitu berkembangnya potensi peserta didik agar menjadi manusia yang beriman dan bertaqwa kepada Tuhan Yang Maha Esa, berakhlak mulia, sehat, berilmu, cakap, kreatif, mandiri, serta menjadi warga negara yang demokratis dan bertanggung jawab.

Patut disadari bahwa kedudukan guru sebagai tenaga profesional dimaksudkan agar guru mempunyai kompetensi ilmu, teknis, dan moral dalam menjalankan tugasnya secara bertanggung jawab dengan jaminan kesejahteraan yang memadai untuk memenuhi hak warga negara memperoleh pendidikan yang bermutu. Bahkan, lebih jauh dari itu, untuk mencerdaskan kehidupan bangsa dengan mecapai tujuan pendidikan.

Perlu ditegaskan bahwa sertifikat merupakan sarana atau instrumen meningkatkan kualitas kompetensi guru supaya menjadi guru yang profesional, untuk sertifikasi guru bukan tujuan melainkan sarana

\footnotetext{
${ }^{8}$ Saud, Udin Syaefudin. Pengembangan Profesi Guru. (Bandung: Alfabeta, 2009). 9.
} 
untuk mencapai tujuan, yaitu menciptakan guru yang berkualitas. Oleh karena itu, perlu diwaspadai adanya kecenderungan sebagai orang yang melihat bahwa sertifikasi guru adalah tujuan, sebab kalau ini yang terjadi maka kualitas guru yang diharapkan tidak akan tercapai.

Sebagai suatu profesi, terdapat sejumlah kompetensi yang harus dimiliki oleh seorang guru, yaitu meliputi kompetensi pribadi, kompetensi profesional dan kompetensi sosial kemasyarakatan.

a) Kompetensi Pribadi

Guru sering dianggap sebagai sosok yang memiliki kepribadian ideal. Oleh karena itu, pribadi guru sering dianggap sebagai model atau panutan (yang harus digugu dan ditiru). Sebagai seorang model guru harus memiliki kompetensi yang berhubungan dengan pengembangan kepribadian (personal competencies).

b) Kompetensi Profesional

Kompetensi profesional adalah kompetensi atau kemampuan yang berhubungan dengan penyesuaian tugas-tugas keguruan. Kompetensi ini merupakan kompetensi yang sangat penting karena langsung berhubungan dengan kinerja yang ditampilkan.

c) Kompetensi Sosial Kemasyarakatan

Kompetensi ini berhubungan dengan kemampuan guru sebagai anggota masyarakat dan sebagai makhluk sosial, meliputi: (1) kemampuan untuk berinteraksi dan berkomunikasi dengan teman sejawat untuk meningkatkan kemampuan profesional; (2) kemampuan untuk mengenal dan memahami fungsi- fungsi setiap lembaga kemsyarakatan dan; (3) kemampuan untuk menjalin kerja sama baik secara individual maupun secara kelompok. 


\section{Kesimpulan}

Dengan adanya program sertifikasi guru diharapkan kinerja guru akan meningkat sehingga mutu pendidikan di Indonesia juga akan meningkat ke arah yang lebih baik. Setelah disertifikasi, diharapkan guru dapat memenuhi empat komponen seperti yang tertuang dalam UndangUndang Guru dan Dosen Pasal 10 dan Peraturan Pemerintah tentang Standar Nasional Pendidikan Pasal 28. Kompetensi guru meliputi empat komponen, yaitu kompetensi pedagogik, kepribadian, professional, dan sosial. Namun, dalam praktiknya, banyak guru yang tidak dapat memenuhi keempat komponen tersebut.

Oleh karena itu, "rujukan dasar" yang digunakan dalam penyelenggaraan sertifikasi guru adalah sosok utuh kompetensi professional guru tersebut. Peningkatan mutu guru lewat program sertifikasi ini sebagai upaya peningkatan mutu pendidikan. Rasionalnya adalah apabila kompetensi guru bagus yang diikuti dengan penghasilan bagus, diharapkan kinerjanya juga bagus. Apabila kinerjanya bagus, maka kegiatan belajar-mengajar pun menjadi bagus. Kegiatan belajar-mengajar yang bagus diharapkan dapat membuahkan pendidikan yang bermutu. Pemikiran itulah yang mendasari bahwa guru perlu disertifikasi.

Undang-Undang Guru dan Dosen (UUGD) telah ditetapkan dan sudah menjadi suatu kebijakan untuk mewujudkan guru yang profesional dan menetapkan kualifikasi dan sertifikasi sebagai bagian penting dalam menentukan kualitas dan kepentingan guru. Upaya sungguh- sungguh perlu dilaksanakan untuk mewujudkan guru yang profesional, sejahtera dan memiliki kompetensi. Hal ini merupakan syarat mutlak untuk menciptakan sistem dan praktek pendidikan yang berkualitas sebagai prasyarat untuk mewujudkan kemakmuruan dan kemajuan bangsa Indonesia.

Sebagai suatu profesi, terdapat sejumlah kompetensi yang harus dimiliki oleh seorang guru, yaitu meliputi;

a) Kompetensi Pribadi

b) Kompetensi Profesional

c) Kompetensi Sosial Kemasyarakatan

Pada akhirnya dapat ditarik kesimpulan bawa sertifikasi sebagai pemicu profesionalitas guru, sehingga kesimpulanya adalah :

a. Guru wajib memiliki kualifikasi akademik, kompetensi, sertifikasi pendidik, sehat jasmani dan rohani, serta memiliki kemampuan untuk mewujudkan tujuan pendidikan nasional. 
b. Kompetensi guru meliputi: kompetensi pedagogik, kompetensi kepribadian, kompetensi sosial, dan kompetensi profesional yang diperoleh melalui pendidikan profesi.

c. Sertifikat pendidik diselenggarakan oleh perguruan tinggi yang memiliki program pengadaan tenaga kependidikan yang terakreditasi juga sertifikasi pendidik dilaksanakan secara objektif, transparan dan akuntabel.

d. Pengembangan professional diperlukan knowledge (pengetahuan), ability (kemampuan), skill (keterampilan), attitude (sikap diri), dan babit (kebiasaan).

e. Kompetensi profesional guru meliputi: kompetensi pribadi, kompetensi profesional dan kompetensi sosial kemasyarakatan. 


\section{Daftar Pustaka}

Fajar, Arnie. Peranan Sertifikasi Guru Dalam Meningkatkan Profesionalisme Guru. Dalam Makalah Seminar Nasional Sosialisasi Sertifikasi Guru dalam memaknai UU No.14 Tahun 2005. Bandung: Disdik Jawa Barat 2006.

Harian Kompas. 4 Desember 2004.

Kunandar. Guru Profesional; Implementasi Kurikulum KTSP dan Sukses dalam Sertifikasi Guru. Jakarta: Rajawali Pers, 2008.

Muslich, Masnur. Sertifikasi Guru Menuju Profesionalisme Pendidik. Jakarta: PT Bumi Aksara, 2007.

Nurdin, Muhamad. Kiat Menjadi Guru Profesional. Jogjakarta: Ar-Ruzz Media, t.t.

Poerwadarminta, W.J.S. Kamus Umum Bahasa Indonesia. Jakarta: Balai Pustaka, 2007.

Saud, Udin Syaefudin. Pengembangan Profesi Guru. Bandung: Alfabeta, 2009. 